\title{
Earnings response coefficients of OECD banks: tests extended to include bank risk factors
}

\begin{abstract}
We investigate two issues: Do share prices of banks in European markets respond to unexpected accounting earnings disclosures? Are share prices as well as unexpected earnings changes correlated with bank-relevant risk factors? Results reveal that bank share prices respond to unexpected earnings changes at the time of accounting reports in the same manner as the shares of the more widely-researched non-bank firms. Apart from finding significant earnings response coefficients in eight countries, we find that credit risk, price risk, exchange rate risk, and solvency risk are significantly correlated with share price changes. Third, three bank risk factors are significantly correlated with unexpected earnings changes. These results are obtained after corrections for several statistical and econometric problems so our reported parameters are robust, certainly more so than in earlier studies using ordinary least square regressions. These new findings extend earnings response literature to several banking sectors, and also identify bank's key risk factors.
\end{abstract}

Keyword: Earnings response coefficient; Share prices; Accounting disclosures; Bank shares; Pooled/panel regressions 